\title{
Kant's Metaphysical System from a New Point of View
}

\section{Schepelmann $\mathbf{M}^{*}$}

BBAW, Germany

*Corresponding author: Maja Schepelmann, BRAW, Kant-Arbeitsstelle der BBAW, Am Neuen

Markt 8, 14467 Potsdam, Germany, Tel: 0049-241-4008644; Email: maja.schepelmann@gmx.de

\section{Research Note}

Volume 4 Issue 1

Received Date: January 07, 2021

Published Date: February 12, 2021

DOI: $10.23880 /$ phij-16000163

\section{Abstract}

Scrutinizing Kant's Philosophy from a Point of View that focuses the whole as the founding beginning for the successively published elements I have come to new research results which are not compatible with the hitherto interpretation of Kant's work.

Keyword: Kant's; Philosophy; Metaphysics Thinking

The complete printed work of Immanuel Kant has usually been interpreted as a series of more or less independent writings. It seems that a connection given by its author is totally missing. Helping for this lack a connection is delivered by its interpreters, at first by its interpreters and researchers in the 19th century. They were convinced that Kant himself has stepwise improved and developed his own thinking and conceiving of Philosophy, so they focused on considering the author's brain as the one and only realm in which thinking about binding the writings together makes sense. With regard to 19th century's positivistic theories about life, about processes of thinking, about society and mankind, this explanation was the most plausible one to cope with several quite puzzling contrasts and contrarieties, partly indeed contradictions, inside different writings of Kant's.

The following considerations cannot deliver a detailed examination of these features or of special Kantian writings. But I shall try to give an overview about my research results ${ }^{1}$ of methodological aspects of Kant's very peculiar way of building a Metaphysical System. There is a lot of research work that is still to be done with regard to conceptual, logical and methodological details of that monumental complete work.

1 Cf. Schepelmann 2017.
All scientific approaches until 2017 order Kant's writings chronologically against the background of his development of thinking, which means to distinguish an older theory from a middle one and a later one. The question is: what is the common thing between them? Do they have nothing to do with each other except representing different phases of the author's improvement in thinking? Is the development idea a good starting point to be able to explain why Kant at first was writing $A$, then $A^{\prime}$ and finally $A^{\prime \prime}$ ? Is it a good idea to suggest that he successively was improving his thinking by reading writings of other authors which give him new impulses and ideas so that he had to change his theory or his favorite concepts?

Concerning the whole of a metaphysical system of Kant's all this ends up in the well-established theory about a philosopher who was despite being a genius quite incompetent in doing the job of grounding and building such a system, who often had to improve his thinking and who let system building things happen instead of planning them thoroughfully. This theory can be called the theory of passive authorship. Until now this one was indeed the only interpreting theory with regard to system building available at all.

According to this theory the whole of Kant's Metaphysics is an aggregate of separate approaches of himself, some of 


\section{Philosophy International Journal}

which were and are treated as really precious and adorable books or writings while others felt into oblivion. I think that this is the most tragic effects of that theory of passive authorship and its interpreting paradigm: only because of the interpreter's approach - not because of the writing's possible difficulties or other worries that might keep us away from reading Kant's texts - only because of interpreters that feel obliged to theoretical approaches of the $19^{\text {th }}$ century people do not read huge parts of Kant's works anymore! A really impressive number of researchers were and actually still are treating Kant under conditions of that very paradigm, which means they treat Kant with the help of the underlying presuppositions and assumptions that derive from $19^{\text {th }}$ century's thinking. Until now nearly everybody in the world takes Kant in the sense of their theory of passive authorship of system building. Until now their presuppositions have never ever been criticized or questioned.

But a closer look into the details of their method of interpretation ends up in the insight that $19^{\text {th }}$ century's researchers have never grounded their presuppositions and assumptions in a proper way or even in any way - in fact they never ever said anything to justify their operations. This is not at all adequate and has to be sharply criticized. Over and above that there are more fishy things with regard to the job philosophers or historians have done.

Kuno Fischer, one of the most powerful historians in $19^{\text {th }}$ century's Germany, created the three-phases-distinction of Kant's work into a pre-critical, critical and post-critical one. Fischer claimed that the first phase, the precritical one, was a phase of dogmatic thinking of Kant's. Only by and after improving his thinking Kant was able to enter the next phase: the critical one. But Fischer completely ignores the stylistic and rhetorical framework in which Kant is presenting his sentences so that Fischer often delivers shortened or incomplete citations of Kant's. ${ }^{2}$

I would suggest to shut down the whole traditional interpretative system and reboot it by considering things differently. If it is true that Kant is one of the most important thinkers of enlightenment, if it is true that he called his own method 'sceptic', ${ }^{3}$ and if it is true that they gave us new

\footnotetext{
2 Cf. Kuno Fischer, Immanuel Kant und seine Lehre, I.151 f., where he cites from Kant's first book Thoughts on the True Estimation of Living Forces (p.23 AA), stating that Kant at that time believed in an objective being of space. But: In this text Kant refers to certain positions of other authors and beds this in quite exposing remarks, like for example saying there are several traditional theories which are easy to prove and showing directly afterwards a lot of their difficulties so that this easiness is problematic: they are not at all easy to prove. This is one example for indirect speech in his writings. So the referrings are surely not to be teached but to be tested. We find hundreds of such forms of presenting thoughts of others in Kant's texts of every period of his thinking.

3 Critique of Pure Reason, A.423 f.B.451.
}

forms of critically reflecting our own and at the same time everybody's conditions of thinking, then it could be that his texts have certain meaning layers. Why not examining the possibility of rhetoric elements in his writings? Why not examining the inner relation between his sort of scepticism and older forms of compose and conceive of texts?

In my opinion Kant's texts of the so-called pre-critical, dogmatic phase should be read by way of including every single stylistic aspect or subtone. The result of such an experimental reading will be: we find a lot of stylistically different treatments of philosophical questions, a lot of rhetoric peculiarities, a lot of irony or mockery and a lot of expressions that can be read in at least two senses.

So a decision has to be made: do we want to assume that all of those peculiarities are results of Kant's errors or shall we try to interpret them in the sense of ambiguous or ironic or figurative speech? I think we have nothing to lose and from a critical and scientific point of view it should clearly be a good idea to try to scrutinize the older approaches of interpretation.

One of my insights is that ironically presented sentences which prima facie seem to be dogmatic do obviously not have this meaning but can be understood as critical intended presentations - so not at the surface of the writings but inside method of conceiving of them we find exactly the same critical efforts as directly uttered in later texts. I would like to underline: Methodologically and conceptionally Kant is a critical thinker also in his earlier and even in his earliest writings.

My way of judging Kant's work from a new point of view results in fact in a new paradigm of interpretation which is not compatible with the usual paradigm of interpreting his texts and his life. My new point of view helps to tell a different story of someone's conceiving of a metaphysical system in a performative sense like a director of a film or of a theater's play would do. So my theory is a theory of Kant's active authorship in building his Metaphysical System. I state that all of his writings are by way of a dramatized composition connected by Kant himself. So it will no longer be necessary to bind them together by way of telling stories about his development in thinking. In my opinion Kant's writings are bound together in a whole - and only this whole is prescribing the functional role of each single writing inside the whole composition.

Besides ironic elements there are also certain irritating positions and claims in Kant. Throughout all of his writings Kant uses them not as direct irony but as parts of a polemical sketch of certain approaches of other philosophers. Kant combines mockery with a kind of educational or didactic 


\section{Philosophy International Journal}

intention of building a philosophical system of Metaphysics in a non-dogmatic way, explicitly stating that he rather wants to teach thinking than results of thinking.

All the irritating claims in his texts have in my opinion a riddle-like function in his system building, and normally there are indirectly exposing subtones in the way they are presented. Later on, in writings that are published some years later, these riddles were solved. But in those earlier, irritating writings Kant carefully provide the readers with every necessary competence and with every suitable knowledge to be able to solve these riddles by themselves before the clarifying writings will appear.

So I would say: Kant's system building is realized by ways of a sceptical method and a rhetorically stage-managed composition which in my opinion clearly was targeted from the very beginning in the 1740 's. Of course not every detail of the later published writings and books was fixed in the beginning but the lines of arguing were. They structure a critical figure of a metaphysical whole that was surely planned as such and in which every writing has its own peculiar function that is determined by that very whole which means: by line and method of arguing. Therefore Kant can be regarded as a sceptical thinker who aims at teaching thinking instead of Philosophy in the sense of textbook knowledge, and who discusses several problems taken from the history of Philosophy as well as from his contemporary debates by way of hypothetic arguments, by way of ironic and satiric presentation and a huge number of provocating passages that aim at irritating the readers' expectations and pushing them into active arguing by theirselves while reading.

Telling that very different story of Kant's system building leads to a re-estimation of everything that formerly was seen as a fault or error of Kant's work. Telling such a story makes it necessary to read (and re-read) all of Kant's writings carefully and with attention towards any possible rhetoric way of treating a thought or a question. Telling such a new story about Kant means also to take into account the many of his philosophical references - most of them quite allusive - that should be regarded as parts of a whole of a critical multi-front commentary that targets at almost every other philosophical author, more or less explicitly, to make clear that transcendental critical philosophy does in no way aim at partiality but at an independent test of argument from a superior, transcendental point of view.

The big plan, the composition of the whole can be analyzed as an argumentation that very often has the form of a hypothetical argumentation. But of course, Kant also presents deductive argumentative parts. It depends on the philosophical work that actually has to be done. The form of the Critique of Pure Reason of course differs from that of nearly every other Kantian text - but taking this into consideration it seems no longer plausible to declare the first Critique as a paradigmatic model of Kant's way of writing. Comparing all his texts rather brings to light that most of them are a stylistic or rhetoric mixture of hypothetic sentences including reductiones ad absurdum, polemic passages, ironic remarks, direct critique towards other authors, deductive arguing including clarifying of the use and usefulness of concepts and conceptual divisions and always in between allusive remarks about philosophical, metaphysical and primarily theological thinking.

So in my opinion Kant's whole work is one single sceptical argumentation and is realized all over the different writings. You just have to put the texts together in one line - from the first one: Thoughts on the True Estimation of Living Forces up to the Opus postumum - and look carefully for the elements that bind them together. And there are really a lot. First of all we have several lines of philosophical problems being discussed and getting transcendental solutions. As sketched out above these lines show many different elements of style. The whole procedure of Kantian discussing is differentiated into certain steps of treating problems in specific ways using specific instruments and techniques.

They all can be interpreted as equal parts of one argumentative unity if and only if it is admitted that the author uses rhetoric and dramatic features in order to present problems in different, sceptical and dramatized ways. Now a careful reading really shows: You do find specific rhetoric and stylistic characteristics in all of Kant's writings, especially irony and mockery.

So my first conclusion is: All writings are intrinsically connected along those lines of discussing philosophical questions.

The option of discovering specific rhetoric and stylistic characteristics in all of Kant's writings, namely especially irony and mockery, is absolutely new information. But why has that point been missed until now? Is it possible that older researchers have made mistakes? The reason could be: with regard to continental philosophy $19^{\text {th }}$ century's thinkers have been totally impregnated by the idea that scepticism has to be eliminated out of philosophy. It seems that the great tradition of scepticism has at that time been totally forgotten; and forgotten was the fact that enlightenment in the sense of programmatic thinking once had been born inside that very tradition. Most of $19^{\text {th }}$ century's thinkers and also a big number of $18^{\text {th }}$ century's thinkers in continental European areas instead were obliged to dogmatic thinking which means amongst other points they were technically dealing with concepts and methods against the background of methodological work done before so that concepts and 


\section{Philosophy International Journal}

methods have already been worked out before arguing. So in those theories the procedure of working out the instruments that are necessary for the philosophical argumentation are not part of that very argumentation itself.

On the other hand side we have sceptic thinkers especially in the $18^{\text {th }}$ century and especially in France, England and Scotland who cultivated scepticism because of its inner value for Philosophy. For them as well as for Kant as a critical thinker the methodological part of working out the instruments and techniques for argumentation must necessarily be part of the arguing itself.

But a lot of his contemporaries were convinced that Philosophy is always aiming at possessing truth. Furthermore they were all accepting that in order to strive for that they more or less automatically split up in different schools, defending different philosophical positions by use of different philosophical methods. The story I want to tell about Kant is the story of someone who was trying to steer in an opposite direction not with regard to content but with regard to method. So I think that Kant was not accepting that there has to be a landscape of philosophical parties. He integrates a lot of concepts and forms of thinking from different sides into his critical System of Metaphysics. And of course Kant was not willing to use the methods of the dogmatics but composed his system differently.

The argumentational whole of Kant's system building is graspable by a threefold receipe:

1. Put all of Kant's writings together in one line - so you get the whole and this whole is functioning as an argumentation.

2. Look for the rhetoric and stylistic elements that bind these writings and lines of discussing problems together - you will find a lot of irony and mockery in Kant.

3. Ask for the reason why he is doing so and remember his dictum that he doesn't want to teach philosophy but that he wants to teach thinking - which means to teach it in a performative way.

If you ask for real proof, I would at first recommend the following considerations:

1. Determinations and definitions of concepts for Kant are only attainable in the end of a discursive process. So Kant's argumentation cannot start with definitions or axioms but has to take over words and concepts out of more or less unjustified uses and to clear and sharpen them step by step.

2. How can we learn to think without a teacher's telling us contents that we more or less have to believe? How can we learn thinking? I have sketched out that this is in fact only partly possible as long as methods and instruments were already fixed by the author to be swallowed by the readers. Kant's critical, sceptical philosophy gives us philosophical riddles and obscurities so that we the readers have to begin to think on our own. His solutions are always given in later writings.

3. Earlier writings and still the writings of the middle of his whole work are full of expressions that are not yet sufficiently determined or that are sometimes even hollow words. In integrating them and playing with possible meanings and claims of concepts Kant is partly caricating the philosophical tradition in which some concepts are quite empty but have sort of an important behaviour. Sometimes his way of adopting concepts is at the same time a combinational adopting of in fact really very different manners of usage in philosophical tradition. Those different manners of other authors have in common that concepts are not sufficiently determined and Kant is exposing that in the sense of a multi-frontcommentary, showing in the end that his own system, logic and conceiving of concepts and theories is absolutely the best one, easily to prove by comparison and confrontation with each of the others theories.

4. The whole argumentative complex consists of irritating processes as well as of normal deductive passages. The irritating processes take place when a concept or a conceptual division is not yet worked out sufficiently, and all those passages function as hypothetical argumentations.

5. With regard to the history of interpreting Kant unfortunately the irritating elements have not been considered as parts of the dramatically and rhetorically composed play of arguments, I would say, but they were acknowledged as symptoms of Kant's unsatisfactory capabilites of thinking.

6. While presenting an argumentation along so many writings and over so many years Kant uses the opportunity not only to comment traditional philosophy but also to adress a lot of commentaries to his contemporaries.

But unfortunately the researchers of $19^{\text {th }}$ century did not take him as a sceptic author. They had not even have the chance to read him that way. And the reason for this could be: they were themselves primarily dogmatic thinkers and did not recognize irony inside Kant's texts. Moreover, they probably have never expected rhetoric features of that kind at all. They instead of that actually very often ignored or brushed aside passages or sentences that show elements of irony and mockery assuming that these passages do not philosophically - make sense.

So indeed the two different ways of reading Kant: one including the option of finding irony, mockery or riddles inside his texts and the other one of only expecting direct speech - they hang together with different grades of thoroughness. 


\section{Philosophy International Journal}

Though admittedly, in my opinion, an adequate form of receptive thoroughness is only reachable if the reading goes beyond one single writing of Kant's and looks for all the different referred theories and positions throughout every writing with regard to one philosophical problem, it has not been completely out of question that older researchers were reading his whole work, as for example Samuel Mellin has done. But even only a local thoroughness in reading, not taking into account the whole work but concentrating just on one text or on a few texts should be able to say something about passages that are not explainable by way of assuming direct speech.

Even if it was in this case not possible to gain insight into the precise sceptical structure of how Kant is treating and solving certain philosophical problems, because that is only possible by reading all texts together as parts of one line of arguing those passages would have required a better answer than the interpreting idea to focus on Kant's greenness or incompetence in philosophical conceiving of a text.

Well, I do not want to accuse people for thinking in herited forms. But I think that it is really a pity that there has been no effort to scrutinize the interpretative presuppositions of the $19^{\text {th }}$ century critically. People seem to believe that those older researchers cannot be wrong. And it could be that this is because we all are still too much obliged to dogmatic approaches of what philosophy can or should do.

Even in his correspondence Kant is very often ironic, a fact that has been missed until now, too. ${ }^{4}$ I have tried to explain how German philosophers in the last days of the $18^{\text {th }}$ century, mainly with the help of Fichte, Schelling and others, were really directly driving into pure dogmatic method and how they have fallen out with each other in quite aggressive manners. They were not able to understand irony or mockery in Kant - and so was - as I tried to sketch out - the next generation.

Well of course: it changes things completely if it is taken into consideration that Kant uses figurative speech in the sense of ironically saying the opposite of what he really intends to say.

All of the texts that has been read under the condition that nearly every passage in Kant has to be understood as uttering direct meaning - all of his texts have to be re-read with a special focus on the possibility of ironic and satiric meanings. But why? Why should he compose his System to such a great amount on behalf of such stylistic and rhetoric elements? Because, that's my answer, he does not only produce a well-grounded and sceptically proved system of

4 Cf. Schepelmann 2018.
Metaphysics on the one hand side but at the same time on the other hand side he gives us a program of enlightenment that is suitable for people teaching themselves in thinking.

His readers have to bring with them the capability of understanding German speech and some basic competence of logic in the sense of common sense ability of arguing. Starting there Kant is teaching them step by step to think on their own, to think independently of any schools. And he does so by using irony and partly by presenting bad and good syllogisms. We the readers have to distinguish between one and the other and we learn out of that performance to get to know method.

In my research I have come to further results. If we admit that ironic elements are not per accident part of most of Kant's writings than we can take into consideration that he might be the author of anonymous publications that have never been ascribed to him. So I claim that he is indeed the author of three hitherto missed books, one is from 1784: Fundament der Kräfte, ${ }^{5}$ and the other ones date from 1799: Stimme eines Arktikers gegen Fichte and from 1800: Sinnlichkeit und Verstand. ${ }^{6}$

So this new point of view is a proposal of absolutely different presuppositions for interpretation. It results in a new paradigm of understanding that is not compatible with the usual standpoint of referring every explication to Kant's development in thinking. The genesis of the latter approach seems in my opinion to root in the specific capacities of the $19^{\text {th }}$ century's researchers who were not able to find subtle irony or mockery in certain philosophical texts and who even were not able to acknowledge the greatness of composers of the enlightenment's century but tried to reduce a lot of things towards being useful as objects of historicism.

\section{References}

1. Immanuel Kant (1746-1749) Thoughts on the True Estimation of Living Forces: Gedanken von der wahren Schätzung der lebendigen Kräfte und Beurtheilung der Beweise, deren sich Herr von Leibnitz und andere Mechaniker in dieser Streitsache bedient haben [...]. Königsberg. $1^{\text {st }}$ (Vol.), AA: Akademie-Ausgabe, pp: 1-181.

2. Immanuel Kant (1787) Critique of Pure Reason: Critik der reinen Vernunft. Königsberg.

3. Immanuel Kant (1784) Betrachtungen über das Fundament der Kräfte und die Methoden, welche die Vernunft anwenden kann, darüber zu urtheilen.

5 Cf. Schepelmann 2017, chapter 8.B.

6 Cf. Schepelmann 2018, chapters 9 and 10. 


\section{Königsberg.}

4. Jäsche GB (1799) (Immanuel Kant), Stimme eines Arktikers gegen Fichte und sein Verfahren gegen die Kantianer. [Without place and publishing company].

5. Anonymus (Immanuel Kant) (1800) Sinnlichkeit und Verstand oder über die Principien des menschlichen Wissens. Eine Kritik über Herrn Herders Metakritik von einem Wahrheitsfreunde. [Without place and publishing company].

6. Immanuel Kant (1796-1803) Opus postumum: Lose
Blätter aus Kant's Nachlass. 21/22 (Vol.).

7. Fischer K (1860) Immanuel Kant und seine Lehre, I: Entstehung und Grundlegung der kritischen Philosophie. 1st (Edn.), relevant here: 6th (Edn.), Heidelberg, Winter 1928.

8. Schepelmann M (2017) Kants Gesamtwerk in neuer Perspektive. Münster, Mentis.

9. Schepelmann M (2018) Der senile Kant?Zur Widerlegung einer populären These. Paderborn, Mentis. 